\title{
The End of Flying: Coronavirus Confinement, Academic (Im)mobilities and $\mathrm{Me}$
}

\section{Mimi Sheller}

\section{Introduction: The Hypermobile Academic}

As I sit here at my home in Philadelphia on a rainy day, nine months into the pandemic (during which I have mostly not travelled at all), my Facebook page keeps sending me photos of 'memories' that I posted long ago: here I am one year ago enjoying a warm, hearty meal with friends in South Korea; here I am visiting a Christmas market in Vienna in 2018; here I am on a beautiful turquoise shore on Rottnest Island, off Perth, Australia, in 2017. These travel memories (all arising from academic work-related trips) precipitate from 'the cloud' as reminders of a time before COVID-19 halted travel. But they are also reminders of what seems like a past age of academic travel. If reducing $\mathrm{CO}_{2}$ emissions in the face of climate change were not enough to get academics to reduce their mobility, perhaps these grim epidemiological and economic realities will force change upon us. As we look towards institutions of higher

\footnotetext{
M. Sheller $(\bowtie)$

Drexel University, Philadelphia, PA, USA

e-mail:mbs67@drexel.edu 
education facing constrained budgets, cutbacks on research funding and staff reductions, will we hold onto the necessity to limit academic travel?

As Higham et al. argue, 'Academics and their institutions are high emitters that have been generally unwilling or unable to respond to the urgency of aviation carbon mitigation' (Higham et al., 2019: 612), generating a crushing sense of 'climate hypocrisy' (Higham \& Font, 2020). Academic 'jet-setting' has been identified as especially problematic (e.g. Høyer, 2009; Smyth, 2010; Nevins, 2014) and seems to be indicative of the extreme differentials in 'mobility capital' of 'kinetic elites' (Sheller, 2018). I count myself among those kinetic elites, despite the fact that I study mobility justice and devote my career to a critique of inequities in mobility. The field of mobilities research has been studying 'aeromobility' for some time (Adey et al., 2007; Urry, 2010), and many studies have shown it to be 'a site of social and environmental injustice' (Higham et al., 2019: 612). Yet we continue to hold many events around the world, to build international networks of research and to meet frequently with our colleagues.

While the work-sociology of academic aeromobility has focused on the importance of co-presence and 'meetingness' (Urry, 2003), and the degree to which these might be substituted by 'virtual mobility', the COVID-19 pandemic has introduced a drastic new factor into this discussion. The COVID-19 pandemic caused the sudden closure of borders and brought to a halt much air travel around the world. Globally air travel experienced a 60-90 per cent decrease in daily activity during confinement level 3. In some ways, this prefigured a world of radically reduced mobilities as climate activists like Greta Thunberg have demanded. What is the impact of this reduction of air travel on academic work and how can it be extended into the future?

According to a comprehensive analysis by Le Quéré et al. in Nature Climate Change, the decrease in $\mathrm{CO}_{2}$ emissions from surface transport during the pandemic accounted for 86 per cent of the total reduction in global emissions; however, the aviation sector 'yielded the largest relative anomaly [in emissions] of any sector' and contributed 10 per cent of the decrease in global $\mathrm{CO}_{2}$ emissions (Le Quéré et al., 2020: 648, 650). While reducing surface transport had a larger impact on emissions, it also came with extreme economic pain. If air travel is a more discretionary 
activity, it seems like a good target for emissions reduction, especially when it engages a small percentage of 'kinetic elites' (Sheller, 2018), including academics.

Civilian aviation is calculated as contributing about 2.8 per cent to global fossil $\mathrm{CO}_{2}$ emissions, which does not seem like that much compared to other human activities such as power generation ( 44.3 per cent), industry (22.4 per cent), surface transportation (20.6 per cent) or even residential (5.6 per cent) (Le Quéré et al., 2020: 648). On the other hand, most of these other emissions-producing activities are utilized by the majority of the population in the industrialized world. Air travel is used only by a small percentage of people, including many academics. We know that a minority of people do the majority of flying. In the United Kingdom, for example, 15 per cent of the population is responsible for 70 per cent of flights (Carmichael, 2019). In the United States, two-thirds of adult airplane trips were taken by those flying $6+$ times per year in 2017. Fewer than half of Americans fly at all in any given year, and around the world, only one in five people have ever flown (see Fig. 3.1). ${ }^{1}$ Thus academic aeromobility is a crucial example of mobility injustice.

Among frequent flyers, academics 'are part of the hypermobile lifestyle', as Klöwer et al. point out through an analysis of the carbon footprint of one major conference: 'The sum total of travel associated with attendance at one large scale academic conference can release as much $\mathrm{CO}_{2}$ as an entire city in one week' (Klöwer et al., 2020: 356). They show that one meeting of the American Geophysical Union (AGU) attracted 28,000 delegates who travelled a collective 285 million kilometres, emitting about 80,000 tonnes of $\mathrm{CO}_{2}\left(\mathrm{tCO}_{2} \mathrm{e}\right)$. Academics have been aware of this anomaly for some time, and many have already taken action to reduce or even fully eliminate air travel (e.g. Tyers, 2019; Høyer, 2009). This phenomenon of 'decarbonizing academia' and challenging 'climate hypocrisy' (Higham \& Font, 2020), however, has not taken hold widely in the United States, where I am based, and is only just starting to emerge.

I can count myself among this minority of hypermobile academics, among the 12 per cent of American adults who have averaged 6+ flights per year over the past ten years. What would it look like to track the carbon footprint of a decade of my own academic travel? How does this 


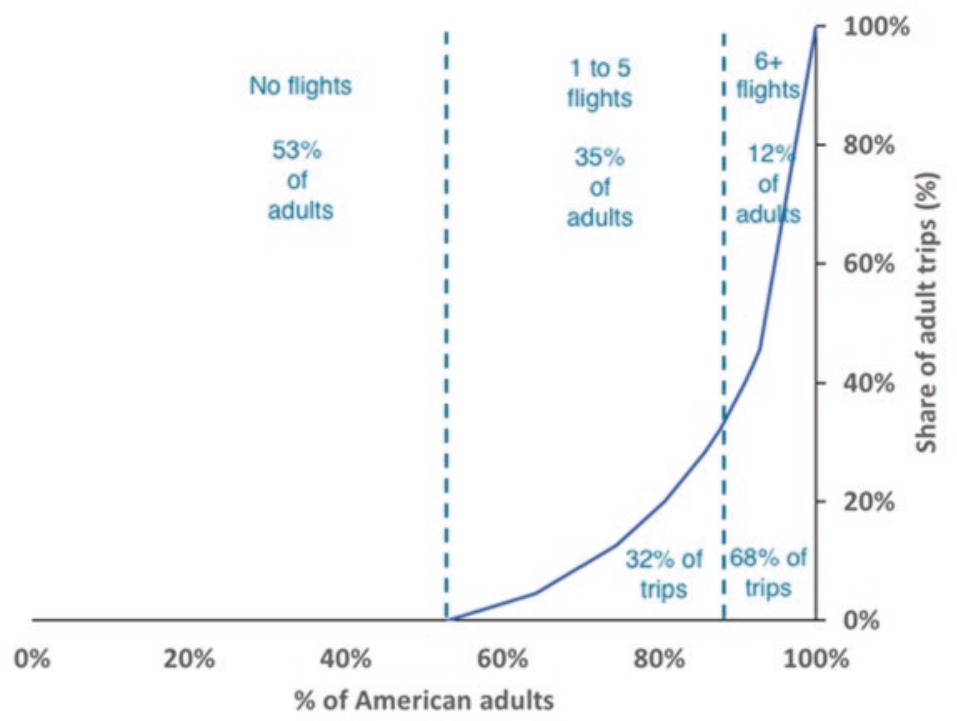

\section{icct}

Fig. 3.1 Cumulative share of airplane trips by American adults, 2017. From the International Council on Clean Transportation

travel correlate with some measure of academic productivity, network connectivity or public impact? And what other more qualitative measures of intrinsic 'value' could be attributed to such academic travel? I decided to set out to try to quantify my own air travel, and to try to assess its value both quantitatively and qualitatively, and what would be required to reduce it.

In the first part of this article, I present my academic travel profile, measure my personal $\mathrm{CO}_{2}$ emissions from professional air travel and assess it against other equivalent measures of emissions. I seek to re-read my curriculum vitae as an itinerarium vitae, as well as to analyse some of the reasons that contribute to my academic 'hyper-mobility'. The C.V. is an interesting record of academic 'achievement', which is full of expectations of travel and the baggage of showing 'international' scholarship. Postcolonial scholars have for some time criticized such measures of international distinction that are often far more difficult to afford from 
places on the peripheries of dominant airline networks. Yet few have unveiled the C.V. as an actual travel itinerary that is an accounting system to measure the material impact of carbon footprints. My method, therefore, is to transform the vertical social mobility of academic achievement, which the C.V. is meant to represent, into an unintended carbon calculator of spatial aeromobility.

In the second part, I seek to evaluate my itinerarium vitae in terms of both quantified academic 'productivity' (i.e. publications, H-index) as well as considering the qualitative aspects of what my international travels have contributed to my life experiences and my scholarship. Following Cresswell (2021), I interrogate the meanings of travel, the embodied experience, what we value in travel and what might be lost in giving it up. In the final section, I look at the rise of virtual academic events in 2020, during the period of pandemic confinement, and consider the extent to which online meetings can substitute for physical travel. I will take into consideration my post-pandemic participation in virtual events and consider how these might be encouraged moving forward.

\section{Coming Clean: My Academic $\mathrm{CO}_{2}$ Footprint}

While an academic curriculum vitae is often read as a proud accumulation of accomplishments, in the era of flygskam (or 'flight-shaming') (Coffey, 2020), it can also be read as a litany of excessive travel. My own C.V. records a weighty tonnage of $\mathrm{CO}_{2}$ emissions, averaging more than six flights per year and adding up to nearly 35.5 metric tonnes of $\mathrm{CO}_{2}$ over the past decade, 2010-2020 (see Table 3.1; see appendix for individual flight data). In Table 3.1 I have included all academic professional events to which I flew over the past decade, divided into domestic flights within the United States, and international flights, with the emissions calculated for each flight using the carbon emissions calculator of the International Civil Aviation Organization.

The events counted include travel for delivering invited lectures and keynote addresses, attendance at conferences, workshops and annual meetings, teaching at $\mathrm{PhD}$ summer schools, consulting or international advisory work and funded research fieldwork. It includes destinations in 
Table 3.1 Total academic work flights taken by author over the past 10 years, with total $\mathrm{CO}_{2} \mathrm{~kg} /$ flight calculation (see appendix for individual flight data)

\begin{tabular}{lcccc}
\hline & Domestic & International & Total Trips/yr & Total $\mathrm{CO}_{2}$ \\
\hline 2010 & 5 & 5 & 10 & 4403.4 \\
2011 & 1 & 3 & 4 & 2815.0 \\
2012 & 4 & 7 & 11 & 5364.1 \\
2013 & 1 & 4 & 5 & 2344.7 \\
2014 & 0 & 3 & 3 & 2093.0 \\
2015 & 2 & 4 & 6 & 3298.8 \\
2016 & 0 & 5 & 5 & 3118.4 \\
2017 & 3 & 3 & 6 & 4013.1 \\
2018 & 1 & 5 & 6 & 3781.8 \\
2019 & 2 & 4 & 6 & 3802.8 \\
2020 & 0 & 1 & 1 & 382.6 \\
TOTAL & 19 & 47 & 66 & $35,417.7$ \\
\hline
\end{tabular}

North America, Latin America, the Caribbean, Europe, Asia and Australia. The tally excludes regional travel for events in the Northeast of the United States, for which I travelled by train, that is, all events in Greater Philadelphia, New Jersey, New York, Delaware and Washington, D.C., all of which I could reach by local trains or Amtrak national rail service, which operates one of the few higher-speed rail services in the United States. It also excludes any personal travel unrelated to work obligations. In many cases, though, I engaged in 'trip chaining' by linking together multiple work obligations in nearby places, and I also left time around work to engage in more social meetings and various forms of tourism.

Almost all the travel recorded here was paid for either by hosting organizations who invited me, or research grants, apart from a handful of conference events that were paid for by my departmental travel funds. Such travel funding generally includes reimbursement for ground transport to and from airports, hotel rooms and most meals. In that sense, these trips were 'free' for me personally, and that is one of the key incentives of academic travel and indeed a perk of the job. With that said, it should be noted that this entire practice of academic hypermobility is underwritten by the unpaid domestic labour of my partner, who stayed home and took care of our two children during my travels, occasionally assisted by my mother. I am lucky that he is an artist who works from a 
home studio, so was flexible and available when needed, and that we live near extended family in the city where we both grew up.

Clearly, this amount of travel is not available to all academics, depending on their career stage, bodily abilities, family circumstances, health status and other personal factors. Travel may also be constrained by citizenship, visa rules, racial/ethnic discrimination and other exclusions. It should be said that I have valued and had the opportunity for such travel throughout my life, and in that regard, I come from a very privileged position of 'mobility capital' (Sheller, 2018). I had travelled throughout Europe, the Caribbean and even Peru and Egypt before the age of 13. I fully understand and speak some French, and I can read and partly understand Spanish, Italian, Portuguese and Haitian Kreyol. I am familiar with navigating new cities, using public transit internationally and communicating in restaurants. My own ease with travel feeds into my propensity to travel, and my travel habitus, which adds to further comfort in international contexts in a kind of feedback effect that instigates further travel.

So how do we interpret what this 35.5 metric tonnes of carbon mean? The United States Environmental Protection Agency (EPA) greenhouse gas equivalency calculator tells me that my air travel emissions are equivalent to 7.7 passenger cars driven for one year, or 3985 gallons of gasoline consumed or 4.1 homes' energy use for one year. ${ }^{2}$ It also tells me that to offset this amount of emissions by carbon sequestration would require 586 tree seedlings grown for 10 years or 46.3 acres of U.S. forests in one year. As the EPA explains,

The greenhouse gas equivalencies calculator can help you understand what reducing carbon dioxide (CO2) emissions by 1 million metric tons means in everyday terms. It is a web-based calculator to help communicate your greenhouse gas reduction strategy, reduction targets, or other initiatives aimed at reducing greenhouse gas emissions. It helps by translating abstract measurements into concrete terms you can understand.

While this was helpful in understanding the scale of my personal impact, I also doubted the veracity of such measures. Given that the United States has weak regulation of the energy efficiency of cars and homes, I also checked the numbers against a similar Canadian calculator. For Canada, 
I found that my emissions would be equivalent to 10.9 passenger vehicles, 15,000 litres of gasoline consumed, of 8.3 homes' energy use for one year. My carbon footprint is even worse when measured in Canadian terms and shows how relative such measures are; imagine if I were comparing to households in Europe or India. ${ }^{3}$ In any case, it was clear that I had a binge-flying problem as a 'high-flying' academic.

What drives such extreme air travel? This period of 2010-2020 in some respects represents my 'peak travel' period, when my career was well established, my international contacts were extensive and my work was extremely international. By whatever measure of the impact, this is an exceptionally high degree of air travel due to several converging professional factors:

a) Having established my career in the United Kingdom before moving back to my home country, the United States, my academic networks were already connected to Europe, hence were likely to be more widespread than academics who have worked solely within U.S. institutions.

b) My research focus on the Caribbean region also connected me with work in that region, including several trips to Haiti and the Dominican Republic for research, as well as presentations at conferences held in the Caribbean region during this period.

c) I also became president of the International Association for the History of Transport, Traffic and Mobility, from 2014 to 2017, which contributed to wider travel commitments because our conferences were held in different countries each year.

d) My research is also highly interdisciplinary, which means I attended conferences related to multiple disciplines and was invited to give talks at a wide range of venues, spanning for example, sociology, geography, communication and media studies, regional and area studies, history and cultural studies.

However this pattern of travel occurred, and however I might justify it, all of my travel came to a screeching halt in February 2020, with my last flight taken only one month before the COVID-19 pandemic shut down most air travel, a topic I return to later. But first I want to consider some 
measures of the value of this academic aeromobility, both quantitatively and qualitatively measured. What value is gained from such travel, both professionally and personally? And what would be lost in ending it?

\section{The Value Proposition of Academic Travel}

One way of measuring the 'value' of an academic career is in terms of research productivity, that is, publications and impact. This is a measure often used in annual assessments of faculty, and in research quality assessments of departments and universities. One of the key justifications of academic aeromobility is that it is necessary for the production of 'national' and 'international' research. In my own case, many of the talks that I wrote for various conferences and events, or travel to conduct research, did directly result in a publication. We can measure this productivity through an enumeration of journal articles, chapters in books, coedited books or journal special issues, sole-authored books or other published work in this ten-year period. Table 3.2 offers an annual overview of my publications and shows a cumulative 110 publications, averaging 11 publications per year over this decade.

Table 3.2 Total number of academic publications by the author, 2010-2020

\begin{tabular}{|c|c|c|c|c|c|c|}
\hline & $\begin{array}{l}\text { Journal } \\
\text { articles }\end{array}$ & $\begin{array}{l}\text { Chapters } \\
\text { in books }\end{array}$ & $\begin{array}{l}\text { Co-edited } \\
\text { books or } \\
\text { special issues }\end{array}$ & $\begin{array}{l}\text { Sole- } \\
\text { authored } \\
\text { books }\end{array}$ & $\begin{array}{l}\text { Other } \\
\text { published } \\
\text { work }\end{array}$ & $\begin{array}{l}\text { Annual } \\
\text { total }\end{array}$ \\
\hline 2010 & 1 & & & & 3 & 4 \\
\hline 2011 & 4 & 3 & & & 1 & 8 \\
\hline 2012 & & 4 & & 1 & 1 & 6 \\
\hline 2013 & 5 & 7 & & & 5 & 17 \\
\hline 2014 & 7 & 6 & 1 & 1 & 2 & 17 \\
\hline 2015 & 5 & 3 & 2 & & 3 & 13 \\
\hline 2016 & 6 & 1 & 4 & & 5 & 16 \\
\hline 2017 & 3 & & 1 & & 1 & 5 \\
\hline 2018 & 4 & 6 & 2 & 1 & & 13 \\
\hline 2019 & 1 & 2 & & & 4 & 7 \\
\hline 2020 & 1 & 3 & & 1 & 4 & 9 \\
\hline TOTAL & 32 & 35 & 10 & 4 & 29 & 110 \\
\hline
\end{tabular}


While these are not all equivalent in terms of the amount of work time going into their production or their potential impact, we could broadly say that in terms of $\mathrm{CO}_{2}$ emissions due to air travel, that I have averaged around $322 \mathrm{~kg}$ of $\mathrm{CO}_{2}$ equivalent per publication. There is no way to correlate publications directly with air travel in any given year given the variability of publication time frames, nor does this represent the total 'carbon footprint' of publishing itself, which of course involves paper production, shipping and digital energy consumption. Rather, my aim here is to discuss the ways in which academic hypermobility might (or might not) be justified in terms of productivity. Nor is this meant to be representative of all academics. I simply want to explore whether in my individual case, we might say that high mobility has some kind of measurable value if it can be correlated with high productivity.

Presenting work to a live audience is an important way to focus one's ideas and communicate them to specific groups. For me, it helps to elicit ideas that then feed into publications. The purpose of academic conferences and invited lectures is sharing and circulation of knowledge, exposure of ideas to feedback and critical dialogue, and the chance to learn from others working in related or adjacent fields. It is also seen as a way of growing professional networks, gaining potential readers and spheres of influence, thus creating an 'international impact' for one's work. While print culture, libraries and electronic distribution achieve some of these aspects of circulation across borders, they are not the same as facing a live audience, engaging in dialogue and the give-and-take of live conversations. The personal interactions before, during and after live events help to crystallize ideas into publications and feed publications into conversations that become knowledge networks.

Another way to measure the impact of one's work would be in terms of the H-index, which measures academic citations. On Google Scholar, my citations grew from 733 in 2010, rising steadily to 1442 in 2015, and then averaging over 2000 per year, from 2016 to 2020. This adds up to an $\mathrm{H}$-index of 37 since 2015, or 44 overall. This suggests that my publications are being widely cited and have made an international impact in terms of their circulation within the scholarly literature. This suggests an 'extrinsic' value apart from any 'intrinsic' value this work might have for me. When seeking jobs, tenure or promotion, academics are required to 
show objective measures of the impact of their work, and being able to show international citations, along with invitations to international events, is part of the measurement of such 'success'. But it also brings with it the feeling of being part of a larger conversation happening around the world, and the give-and-take of academic fields that are constantly growing along a fractal edge.

Yet these numbers do little to convey the importance of academic mobilities in a more personal or experiential sense. Higham et al. note the increased blurring of 'the lines between work and non-work spaces, business and leisure time, and colleagues and friends', leading to an 'interplay of professional, social and personal factors' that encourage academic travel (Higham et al., 2019: 616). This has certainly been my experience of work-related travel. Part of the mobile academic lifestyle also involves getting to know people around the world, experiencing other cultures and having the opportunity to make connections with researchers in multiple regions of the world.

Academic travel gave me incredible opportunities to experience other cultures and places, to meet people around the world and to connect my work to many others. I savour my experiences of the major Asian cities such as Tokyo, Hong Kong, Singapore and Seoul, all of which I might never have visited otherwise. In Seoul, to give just one in-depth example, I am deeply grateful to my generous host, Jin Hyeoung Lee at Konkuk University, who served not only as an academic organizer but also as a tour guide. I got to eat incredible Korean meals (see Fig. 3.2), visit stunning historical sites around Seoul (see Fig. 3.3) and learn about Korean history in museums and heritage sites. I learnt more about Korean history and culture than I had in my life.

Moreover, this was not simply to give a talk there, but also part of establishing a long-term research relationship with the new Academy for Mobility Humanities (AMH), joining their advisory board, assisting them in creating a new journal, signing a Memorandum of Understanding with my university and becoming part of an ongoing research project. This relationship of 'network sociality' (Urry, 2003) will undoubtedly lead to future virtual events as well as possible in-person visits, building up 'network capital' at both ends (Higham et al., 2019). AMH also have a commitment to translate texts into Korean, including my own book 


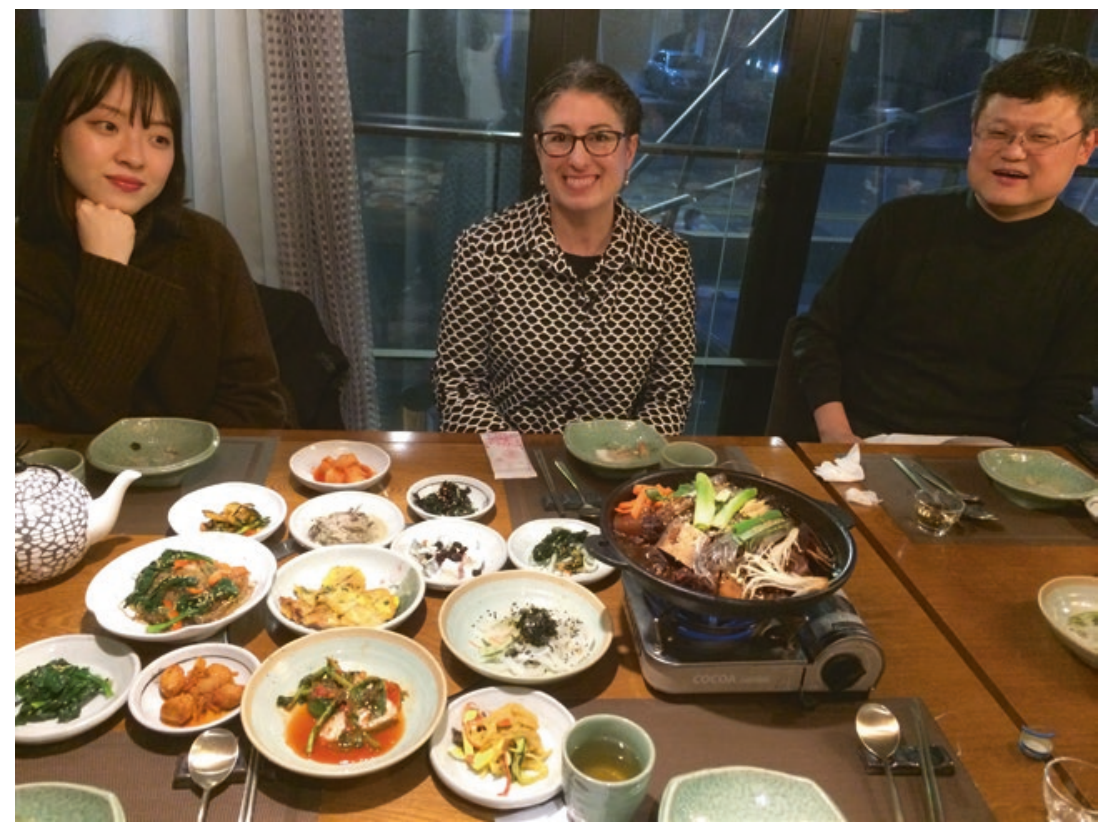

Fig. 3.2 The author dining with Jin Hyeoung Lee and Geun-Sung Lee at a Seoul Restaurant

(see Fig. 3.4), thus contributing to intercultural exchange and conversation across national academic locations and disciplines. Taken together, then, this academic travel experience had many positive qualities and high value.

Likewise, I benefitted immensely from travel throughout major cities in Europe, as well as smaller regional cities that I might not have visited otherwise. Despite limited time for each trip due to work obligations, in each city I visited I usually had time to visit a museum, dine on the local cuisine and learn about the culture. And I had opportunities for rich immersion in Latin American capitals like Mexico City and Santiago, Chile as well as Caribbean capitals like Kingston (Jamaica), Bridgetown (Barbados) and Port-au-Prince (Haiti). I was incredibly moved by my research in Haiti after the 2010 earthquake, and further research there in 2013 that involved crossing the Dominican Border for the first time, a 


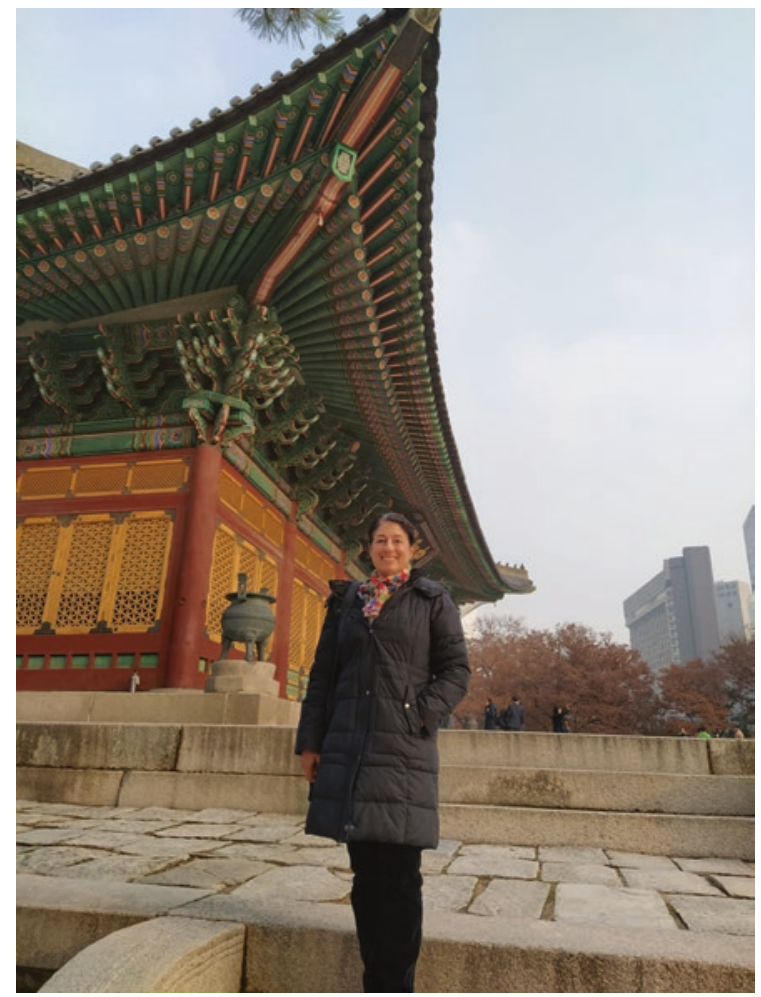

Fig. 3.3 The author visiting a historic heritage site in Seoul

research experience that became part of my latest book (Sheller, 2020a) which reflects on my travels there over the entire decade.

My academic travel, in other words, is inseparable from academic 'tourism' as a chance for cultural experience and international exchange, but it is also part of my research topic which is the study of mobilities. As someone who studies mobilities, my own experiences of travel become part of what I study, including passing through various airports, the affective experience of being an air passenger (Budd, 2011), observing border checkpoints and reflecting on citizenship and racial inequalities in various countries. My research also involves knowledge of various transportation systems, so a wide experience of a wide variety of different train, tram, bus, ferry and bike systems is important to my knowledge base. 


\section{MHIO6}

Mobility

Humanities
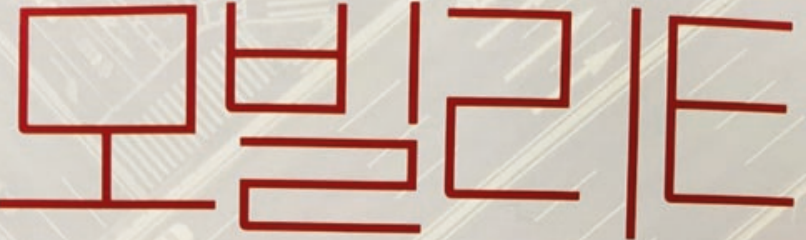

미미 셸러 지음 | 최영석 옳김
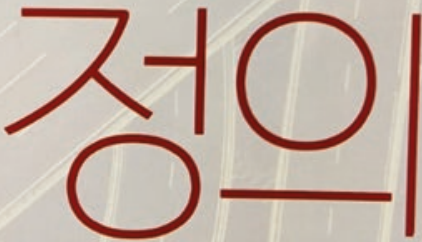

세분화되고 위기에 처한 세상에서 연대가 필요한 사람들의 필독서 인종차별 적 정책 수립에서부터 인간의 이동이 기후변화에 미치는 영향에 이르기까지, 이동성 정치에 관한 필수 현장 가이드. 더 나은 세상을 상상하고 실현하기 위 해 우리가 이동하는 방식을 이해하고 행동해야 할 시급성을 분명히 보여 준다.
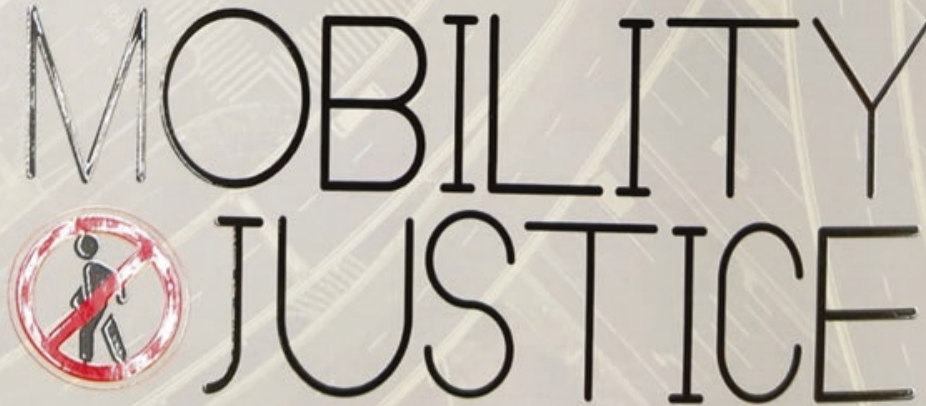

OMIII

Fig. 3.4 My book, Mobility Justice, translated into Korean 
And, indeed, tourism itself is one of the subjects I study, so as I travel I am always also reflecting on these different dimensions of mobilities, and associated immobilities, moorings and meanings. From the perspective of my own field of study, therefore, travel is a catalyst to new ideas, triggering research questions that might not otherwise have occurred to me, and thereby contributing to my research productivity. I can write more knowledgeably about various modes of transport, or different international airport experiences because I have travelled through them.

Finally, in a few cases, I was able to take my family with me to academic events, enabling my partner and children to enjoy tourist experiences, for example in Hong Kong and Macao, or in Barbados and Guadeloupe. Many academics find it difficult to juggle home life and travel obligations or to afford familial travel. Junior academics, firstgeneration graduates, academics from groups discriminated against in travel contexts and simply those with less travel experience and without a reservoir of 'mobility capital' — not to mention financial capital—might find it much more challenging to engage in these practices, even though it may be a professional expectation. Yet, for others, flying may help them to balance this work/family dynamic because circumstances have led them to work in different places. Air travel is that which divides us but also that which connects us.

\section{The Virtues of Virtual Mobilities}

While calls for flight reduction had been growing across academic circles, especially in Europe and the UK for some time, in the United States it took the coronavirus to halt academic travel. The pandemic demonstrated our ability to transform academic events and accelerated the use of remote meetings. A key question then arises: How do we find ways of extending this abnormal situation into the post-pandemic reopening of travel? Klöwer et al. (2020) make several recommendations on how to cut down on academic travel. In calling for academic conferences to be reimagined, they argue based on their measurements of one major international conference that three policies would have the greatest impact on reducing $\mathrm{CO}_{2}$ emissions: (a) choosing accessible venues (based on 
modelling attendee journeys to reduce long-haul flights); (b) increasing virtual attendance and (c) major conferences becoming biennial rather than annual, with virtual events every other year.

My own experience of switching to online events during the pandemic confinement might be instructive, especially when contrasted with my previous hypermobility. Apart from a single flight to an event in Jamaica in late January 2020, all my academic activities moved online. My virtual participation in conferences, webinars and invited talks in 2020 is summarized in Table 3.3, along with several cancelled events and where they would have been.

Overall, my experience in 2020 is that, initially, I had event cancellations that led to avoiding two domestic flights (FL, GA) and two international flights (Belgium, Canada). Then, as event organizers adapted to online environments, I was able to keep up my usual pace of activities. This included delivering online 7 invited talks or keynote lectures, attending 9 invited panels or workshops and holding 15 other remote meetings or events (excluding my own university's events and meetings). In so doing, I avoided 4 international flights, participated in many international events that I might otherwise have missed and was able to conduct a number of remote interviews and other international activities. This list excludes many other webinars that I was able to watch simply as an audience member. Indeed, over the past 10 months, if anything, I participated in more events than usual: I fully replaced my physical hypermobility with a kind of virtual hypermobility.

While publications that might result from this period of activity are still in progress, I can attest that I have an unusually high number of works in progress and forthcoming (which I know because I have to report on and quantify this in a Faculty Annual Review each year). This tally includes a book completed in the summer of 2020 that will be published in March 2021, a journal special issue I am co-editing that will be published in February 2021, at least six refereed journal articles and book chapters already submitted and at least a dozen other invited book chapters, commentaries and other small pieces in progress. Indeed, it appears there may even be a quantitative increase in my productivity since the hurdles of international virtual participation are lower than having to travel, and many virtual events lead to a publication of some kind. 
Table 3.3 Online events the author participated in during the 2020 COVID-19 pandemic confinement

\begin{tabular}{|c|c|c|c|}
\hline & $\begin{array}{l}\text { Invited talks or } \\
\text { keynote lectures }\end{array}$ & $\begin{array}{l}\text { Invited participation in } \\
\text { workshops/panels }\end{array}$ & $\begin{array}{l}\text { Other online events, } \\
\text { webinars, meetings }\end{array}$ \\
\hline March & $\begin{array}{l}1 \text { Keynote cancelled } \\
\text { (FL) }\end{array}$ & & \\
\hline April & $\begin{array}{l}1 \text { Talk cancelled } \\
\text { (GA) } \\
2 \text { Talks cancelled } \\
\text { (Belgium) }\end{array}$ & & \\
\hline May & & $\begin{array}{l}2 \text { events cancelled } \\
\text { (Montreal, } \\
\text { Philadelphia) }\end{array}$ & \\
\hline June & & $\begin{array}{l}1 \text { Conference panel } \\
\text { (Canada) }\end{array}$ & $\begin{array}{l}1 \text { Research meeting } \\
\text { (Aalborg } \\
\text { University) } \\
1 \text { Webinar (CA) } \\
1 \text { PhD viva (NC) }\end{array}$ \\
\hline July & & 1 Workshop (Ontario) & $\begin{array}{l}1 \text { Virtual island } \\
\text { summit }\end{array}$ \\
\hline August & $\begin{array}{l}1 \text { Lecture \& online } \\
\text { Q\&A (Aalto) }\end{array}$ & $\begin{array}{l}1 \text { Online broadcast } \\
\text { (Phila) }\end{array}$ & 1 Interview \\
\hline September & $\begin{array}{l}1 \text { Invited talk (U } \\
\text { Penn) } \\
1 \text { Invited talk } \\
\text { (British Columbia) }\end{array}$ & 1 Remote panel (LSE) & $\begin{array}{l}1 \text { Radio show } \\
\text { (Jamaica) } \\
1 \text { Webinar (Dublin) }\end{array}$ \\
\hline October & $\begin{array}{l}1 \text { Invited talk } \\
\text { (Aberystwyth) } \\
1 \text { Keynote panel } \\
\text { (Lancaster) }\end{array}$ & $\begin{array}{l}1 \text { Workshop (U Penn) } \\
1 \text { Academic conference } \\
\text { panel (HSA, } \\
\text { Washington) } \\
1 \text { Online forum (EU) }\end{array}$ & $\begin{array}{l}1 \text { Virtual symposium } \\
\text { (Princeton) } \\
1 \text { Interview } \\
\text { (Belgium) }\end{array}$ \\
\hline November & $\begin{array}{l}1 \text { Invited lecture } \\
\text { (Paris) }\end{array}$ & 1 Invited panel (EU) & \\
\hline December & $\begin{array}{l}1 \text { Invited class } \\
\text { lecture (NY) }\end{array}$ & $\begin{array}{l}1 \text { Online conversation } \\
\text { (Phila) }\end{array}$ & $\begin{array}{l}1 \text { Advisory board } \\
\text { (UK) } \\
1 \text { Training event (US) } \\
4 \text { Online events }\end{array}$ \\
\hline TOTAL & 7 & 9 & 15 \\
\hline
\end{tabular}

It could be concluded, then, that the move to virtual academic mobility has not quantitatively impacted on the number of events I have been involved in, and possible publications that might result from these events. At least for me as a social scientist, not requiring lab space, my ability to 
work from home has only required a good broadband internet connection. On the other hand, has there been a qualitative diminishment in the quality of interaction with colleagues? I first note that in about half of the events listed here I already knew 'in person' the host or organizer, so my pre-existing face-to-face contacts had created the circumstances for the virtual invitation. But this is not always the case, and in some cases, people may have reached out with virtual invitations who might otherwise have been unable to fund my travel. The quality of interaction is sometimes impacted because virtual events do not always go smoothly, and sometimes there are difficulties in internet connections. And there is a lack of casual conversation that takes place before and after meetings, which may lead to a more 'thin' connection to the host and audience.

Second, I lost out on the opportunity of what I have described as academic 'tourism' that usually accompanies some of these events. I had to cancel a trip to Belgium, and I did not get to visit the University of British Columbia, nor go to Aberystwyth or Lancaster, where I would have seen old friends and colleagues. On the other hand, I was able to participate in many remote events that there is no chance I would have travelled to, such as the Island Studies conference which was initially supposed to be in St. Johns, Newfoundland. I also discovered digital native events that were always planned to be online, such as the Virtual Islands Summit. Being forced to move their work online, many academics in 2020 have discovered new methods of digital delivery of meetings, events and conferences which have opened them up to wider participation. Qualitatively, this was an important gain in digital experience, if not quite as satisfying as meeting with people and places in person.

Third, the experience of the COVID-19 confinement and the closure of air travel have ultimately changed the meaning of air mobilities for everyone, including academics. Many people are now fearful of travel in confined spaces. Others long to return to the air, but will perhaps value the experience more highly and appreciate that they are able to travel. Many have reconsidered what they value most, which for some includes revaluing activities closer to home, but for others includes missing farflung family and friends whom they have been unable to visit in other countries. The mixture of work-life, home-life and travelling takes on a 
new 'hybrid space' quality (de Souza e Silva \& Sheller, 2014) as we all have found creative ways of connecting our physical presence and digital worlds, perhaps for the better.

\section{Conclusion: Flying After the End of Flying}

The COVID-19 confinement has instigated a reorganization of many aspects of academic travel that seemed to be 'locked in' and difficult to change (Higham et al., 2019). It has pushed the pace of change in adopting digital communications and virtual meetings; it has normalized these practices and it has left no excuse for not meeting virtually. Moreover, with or without flight shaming, many academics may be forced to reduce their flying for economic reasons. As the pandemic continues, airlines and airports are under extreme financial pressure causing them to cut back routes and flight schedules, as are universities. Some airlines and airports may go bankrupt (especially smaller regional ones), and some universities may downscale travel budgets (if indeed they are not also forced to close). We may never return to the 'heyday' of flying as a way of academic life. What, then, can we learn from this period of no flying?

Taking up the three suggestions by Klöwer et al. on decarbonizing conference travel, we could expand these to think about decarbonizing all academic travel. Academics can continue to build regional networks involving mainly train travel; we can continue to hold regional conferences with perhaps networked hubs connecting remotely to other regions, and we can plan for biennial or triennial face-to-face events for major professional organization meetings. If we could do all this while maintaining our networked connections in the hiatuses of travel, we would lose little in terms of academic connectivity and productivity. This will require continued investment in digital tools and meeting technologies and will need universities and professional organizations to make commitments to this transformation. From the perspective of my research and my discipline, I see nothing stopping us from such a travel reduction and no reason to return to the prior expectations of hyper-travel.

Furthermore, we will also lose out on some of those more personal and ineffable aspects of travel that I have described above, which for a social 
scientist are also forms of learning about the world. I will not be able to savour a steaming bowl of Samgyetang (Ginseng Chicken Soup) from the most famous soup-restaurant in Seoul, which was part of a visit to the former U.S. command centre during the Korean War, which I also learnt about. I will not be able to tour new cities, learn about ancient cultures and observe cultural differences, which is part of being a good social scientist. I will not be able to make personal connections with Caribbean colleagues who may find it harder to travel to the United States, like those in Haiti, which is crucial to building academic networks that support thinkers outside the metropoles. For these reasons, perhaps we will hold onto some forms of academic aeromobility, but it cannot simply be in the service of tourism for the kinetic elite to enjoy as a benefit to work travel. As Higham et al. conclude, building on the arguments of John Urry (2003) about social networks, travel and talk, 'At the very least it is necessary that the institutional context foster new interplays of corporeal and virtual mobilities that facilitate co-presence and meetingness in ways that take account of social and environmental inequalities' (Higham et al., 2019: 627). In other words, we need to introduce what I call a mobility justice perspective into planning academic travel.

In other words, professional travel for co-presence should be for the benefit of those least able to engage in such trips; it should aim to build academic capacity in places that are geographically, economically and geopolitically dis-privileged by partnering with local higher education institutions and including students and faculty there; it should be in the service of academic objectives that cannot be met virtually or from a distance, and should be justified in relation to its necessity for meeting those objectives, and it should be more carefully limited for those who are simply enjoying benefits of being at the top of the academic hierarchy. These are the kinds of difficult conversations we need to have within our disciplines and institutions: how will we determine the distribution of the costs and benefits of long-distance travel? And which activities can be replaced with virtual meetings at no harm to the academic enterprise?

We should, therefore, place academic aeromobility within the context of wider discussions of mobility justice and 'Anthropocene mobilities' (Baldwin et al., 2019). I, for one, will consider how I can continue to value some forms of getting together and long-distance travel, while also 
being more careful about its impacts and exclusions. We should also acknowledge the impact of past forms of excessive travel and consider the payment of climate reparations on behalf of those whom it has harmed. In my own work, I have started arguing for climate reparations to be paid through the U.N. climate fund especially to small island states where I do research in the Caribbean, and through lawsuits against fossil fuel companies for loss and damages (Sheller, 2020a, 2020b). Beyond individual responsibility, I believe there is wider institutional responsibility and changes must be made at the macro-structural level, not just in individual behaviour.

Kinetic elites owe a 'climate debt' to others impacted most by climate change. Countries in the Global North and metropolitan centres owe a climate debt to those on the peripheries who have contributed the least to climate change. Universities and individual academics should account for their air travel carbon emissions, and take measures both to reduce them and to offset past emissions; but also should examine the kinds of networks through which academic prestige is built and reflect on supporting and rewarding more local social and environmental transformation in their own regions. But we must also find ways to continue cross-regional and international communication and connection, learning and cultural immersion, so that we do not simply retreat into a dark age of disconnection. To the extent that we can replace physical mobility with digital connections, we must continue to do so; but where cultural exchange is still possible, we must make the most of it.

\section{Appendix: Itinerarium vitae of Mimi Sheller, 2010-2020}

\begin{tabular}{llll}
\hline Date & Origin & Destination & $\mathrm{CO}_{2} /$ journey $(\mathrm{kg})$ \\
\hline 05/03/10 & Philadelphia & Miami & 280.5 \\
$25 / 03 / 10$ & Philadelphia & Pittsburgh & 164.7 \\
03/2010 & Philadelphia & Port-au-Prince & 393.2 \\
$10 / 04 / 10$ & New York* & Vancouver/Victoria & 631.6 \\
$27 / 05 / 10$ & New York & Barbados & 513 \\
$07 / 2010$ & Philadelphia & Port-au-Prince & 393.2 \\
$27 / 08 / 10$ & New York & Isle of Ven $(\mathrm{CPH})$ & 716.8 \\
\hline
\end{tabular}


(continued)

\begin{tabular}{|c|c|c|c|}
\hline Date & Origin & Destination & $\mathrm{CO}_{2}$ /journey $(\mathrm{kg})$ \\
\hline $27 / 10 / 10$ & Philadelphia & CPH/Aalborg, DK & 801.6 \\
\hline $11 / 11 / 10$ & Philadelphia & Providence, RI & 152.2 \\
\hline $17 / 11 / 10$ & Philadelphia & New Orleans & 356.6 \\
\hline $12 / 4 / 11$ & Philadelphia & Seattle & 563.2 \\
\hline 29/4/11 & New York & CPH, Denmark & 716.8 \\
\hline $6 / 6 / 11$ & Philadelphia & CPH/Aalborg & 801.6 \\
\hline 20/10/11 & Philadelphia & Berlin & 733.4 \\
\hline $22 / 2 / 12$ & Philadelphia & Los Angeles & 575.2 \\
\hline $17 / 3 / 12$ & Philadelphia & Durham, NC & 160.2 \\
\hline $01 / 2012$ & Philadelphia & Tokyo & 943.4 \\
\hline 04/05/12 & Philadelphia & Oxford/Aalborg & 877.8 \\
\hline $05 / 12$ & Philadelphia & Oakland & 298.9 \\
\hline $30 / 06 / 12$ & Philadelphia & Guadeloupe & 377.6 \\
\hline 05/07/12 & Philadelphia & Cagliari, Sardinia & 841.3 \\
\hline 24/10/12 & Philadelphia & Chicago & 233.1 \\
\hline 9/11/12 & Philadelphia & Toronto, CA & 235.8 \\
\hline $17 / 11 / 12$ & Philadelphia & Madrid, SP & 660.6 \\
\hline $14 / 12 / 12$ & Philadelphia & Durham, NC & 160.2 \\
\hline 03/2013 & Philadelphia & Port-au-Prince & 393.2 \\
\hline $05 / 2013$ & Philadelphia & Montreal, CA & 216 \\
\hline 23/08/13 & Newark & Hong Kong & 966 \\
\hline 06/09/13 & Philadelphia & Lancaster (MAN) & 613.2 \\
\hline 04/10/13 & Philadelphia & Boston & 156.3 \\
\hline $13 / 10 / 14$ & New York & Santiago, Chile & 708.6 \\
\hline 05/11/14 & New York & Copenhagen, DK & 716.8 \\
\hline $11 / 12 / 14$ & Philadelphia & Paris, FR & 667.6 \\
\hline $19 / 03 / 15$ & Philadelphia & AMS/Eindhoven NL & 637.7 \\
\hline 22/04/15 & Philadelphia & Chicago & 233.1 \\
\hline $05 / 05 / 15$ & Newark & Karlstad, SW & 786.4 \\
\hline $14-18 / 09 / 15$ & Newark & Caserta (NAP)+CPH & 865.3 \\
\hline $14 / 10 / 15$ & Newark & Leiden, Hanover & 620 \\
\hline 09/10/15 & Philadelphia & Boston, MA & 156.3 \\
\hline 26/02/16 & Newark & Singapore & 1299.8 \\
\hline $10 / 07 / 16$ & New York & Port-au-Prince & 393.2 \\
\hline $30 / 09 / 16$ & Philadelphia & Montreal, CA & 216 \\
\hline 28/10/16 & Philadelphia & Mexico City, MX & 474.6 \\
\hline $30 / 11 / 16$ & New York & Stuttgart/Berlin & 734.8 \\
\hline 01/03/17 & Philadelphia & Grinnell/DesMoines & 389.8 \\
\hline 28/03/17 & New York & Vancouver, CA & 631.6 \\
\hline 03/04/17 & Philadelphia & Boston, MA & 156.3 \\
\hline 09/2017 & Philadelphia & Storrs, BDL, CT & 146.4 \\
\hline 27/11/17 & Philadelphia & Sydney \& Perth & 2330.6 \\
\hline $03 / 12 / 17$ & Perth & Melbourne, AUS & 358.4 \\
\hline
\end{tabular}


(continued)

\begin{tabular}{llll}
\hline Date & Origin & Destination & $\mathrm{CO}_{2}$ /journey $(\mathrm{kg})$ \\
\hline $23 / 03 / 18$ & Philadelphia & Waterloo, CA & 235.8 \\
$11 / 04 / 18$ & Philadelphia & New Orleans & 356.6 \\
$20 / 04 / 18$ & Philadelphia & Amsterdam/CPH & 761.3 \\
$08 / 06 / 18$ & Philadelphia & Rome/Florence, IT & 853.6 \\
$07 / 08 / 18$ & Philadelphia & YYZ/Kelowna, CA & 725.1 \\
$18 / 11 / 18$ & Newark & Vienna/Geneva & 849.4 \\
$25 / 04 / 19$ & Philadelphia & Reykjavik & 446.8 \\
$19 / 09 / 19$ & Philadelphia & Manchester, UK & 613.2 \\
$02 / 10 / 19$ & Philadelphia & Miami & 280.5 \\
$13 / 10 / 19$ & Philadelphia & Venice/Paris & 817.8 \\
$1 / 11 / 19$ & Philadelphia & San Francisco & 298.9 \\
$11 / 12 / 19$ & Philadelphia & Seoul, KO & 1345.6 \\
$01 / 30 / 20$ & Philadelphia & Montego Bay, JA & 382.6 \\
\hline
\end{tabular}

Calculated for Roundtrip Economy flights or multi-destination itineraries using https://www.icao.int/environmental-protection/CarbonOffset/Pages/ default.aspx.

*In some cases New York or Newark have been substituted for flights that may have involved a flight from Philadelphia with a transfer at a second city, in order to simplify the calculation as a direct flight.

\section{Summary of the methodology used:}

$\mathrm{CO}_{2}$ Emissions per passenger take into consideration the load factor and are based only on passenger operations (i.e. fuel burn associated with belly freight is not considered). The steps for the estimation of $\mathrm{CO}_{2}$ emissions per passenger:

Step 1: Estimation of the aircraft fuel burn

Step 2: Calculation of the passengers' fuel burn based on a passenger/freight factor which is derived from RTK data

Step 3: Calculation of seats occupied (assumption: all aircraft are entirely configured with economic seats). Seat occupied = Total seats * Load Factor

Step 4: $\mathrm{CO}_{2}$ emissions per passenger $=($ Passengers' fuel burn * 3.16) $/$ Seat occupied Note: for flights above $3000 \mathrm{~km}, \mathrm{CO}_{2}$ emissions per passenger in premium cabin = $2 \times \mathrm{CO}_{2}$ emissions per passenger in economy

\section{Notes}

1. https://www.vox.com/business-and-finance/2019/8/7/20756833/ climate-change-flying-calculator-arctic-ice

2. https://www.epa.gov/energy/greenhouse-gas-equivalencies-calculator

3. https://oee.nrcan.gc.ca/corporate/statistics/neud/dpa/calculator/ghgcalculator.cfm 


\section{References}

Adey, P., Budd, L., \& Hubbard, P. (2007). Flying lessons: Exploring the social and cultural geographies of global air travel. Progress in Human Geography, 31(6), 773-791. https://doi.org/10.1177/2F0309132507083508

Baldwin, A., Fröhlich, C., \& Rothe, D. (2019). From climate migration to Anthropocene mobilities: Shifting the debate. Mobilities, 14(3), 289-297. https://doi.org/10.1080/17450101.2019.1620510

Budd, L. (2011). On being aeromobile: airline passengers and the affective experience of flight. Journal of Transport Geography, 19(5), 1010-1016. https:// doi.org/10.1016/j.jtrangeo.2010.06.017

Carmichael, R. (2019). Behaviour change, public engagement and Net Zero. A report for the Committee on Climate Change. https://www.theccc.org.uk/ publications/ and http://www.imperial.ac.uk/icept/publications/.

Coffey, H. (2020, June 5). Flygskam: What is the flight shaming environmental movement that's sweeping Europe? The Independent. https://www.independent.co.uk/travel/news-and-advice/flygskam-anti-flying-flight-shamingsweden-greta-thornberg-environment-air-travel-train-brag-a8945196.html.

de Souza e Silva, A., \& Sheller, M. (Eds.). (2014). Mobility and locative media: Mobile communication in hybrid spaces. Routledge.

Higham, J., Hopkins, D., \& Orchiston, C. (2019). The work-sociology of academic aeromobility at remote institutions. Mobilities, 14(5), 612-631. https://doi.org/10.1080/17450101.2019.1589727

Higham, J., \& Font, X. (2020). Decarbonising academia: confronting our climate hypocrisy. Journal of Sustainable Tourism, 28(1), 1-9. https://doi.org/1 $0.1080 / 09669582.2019 .1695132$

Høyer, K. G. (2009). A conference tourist and his confessions: An essay on a life with conference tourism, aeromobility, and ecological crisis. Tourism and Hospitality Planning \& Development, 6(1), 53-68. https://doi.org/10.1080/ 14790530902847061

Klöwer, M., Hopkins, D., Allen, M., et al. (2020). An analysis of ways to decarbonize conference travel after COVID-19. Nature, 583, 356-360.

Le Quéré, C., Jackson, R. B., Jones, M. W., Smith, A. J. P., et al. (2020). Temporary reduction in daily global CO2 emissions during the COVID-19 forced confinement. Nature Climate Change, 10(July), 647-653. https://doi. org/10.1038/s41558-020-0797-x 
Nevins, J. (2014). Academic jet-setting in a time of climate destabilization: Ecological privilege and professional geographic travel. The Professional Geographer, 66(2), 298-310. https://doi.org/10.1080/00330124.2013.784954

Sheller, M. (2018). Mobility justice: The politics of movement in an age of extremes. Verso.

Sheller, M. (2020a). Island futures: Caribbean survival in the Anthropocene. Duke University Press.

Sheller, M. (2020b). The case for climate reparations. Mother Jones. https://www. motherjones.com/environment/2020/11/the-case-for-climate-reparations/.

Smyth, K. R. (2010). Air travel and climate change: Should faculty and students be grounded? Sustainability, 3(5), 1-2. https://doi.org/10.1089/sus.2010.9752

Tyers, R. (2019, July). Southampton to Shanghai by train - one climate change researcher's quest to avoid flying. The Conversation. https://theconversation. $\mathrm{com} /$ southampton-to-shanghai-by-train-one-climate-change-researchersquest-to-avoid-flying-120015.

Urry, J. (2003). Social networks, travel and talk. The British Journal of Sociology, 54(2), 191-212. https://doi.org/10.1080/0007131032000080186

Urry, J. (2010). Consuming the planet to excess. Theory, Culture and Society, 18(6), 51-76. https://doi.org/10.1177/2F0263276409355999

Open Access This chapter is licensed under the terms of the Creative Commons Attribution 4.0 International License (http://creativecommons.org/licenses/ by/4.0/), which permits use, sharing, adaptation, distribution and reproduction in any medium or format, as long as you give appropriate credit to the original author(s) and the source, provide a link to the Creative Commons licence and indicate if changes were made.

The images or other third party material in this chapter are included in the chapter's Creative Commons licence, unless indicated otherwise in a credit line to the material. If material is not included in the chapter's Creative Commons licence and your intended use is not permitted by statutory regulation or exceeds the permitted use, you will need to obtain permission directly from the copyright holder.

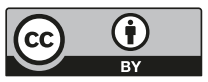

